\section{'TexKing', an Early Ripening, Medium-chill Peach}

\author{
David H. Byrne and Terry A. Bacon ${ }^{1}$ \\ Department of Horticultural Sciences, Texas A\&MUniversity, College Station, \\ TX 77843-2133
}

Additional index words. fruit breeding, medium chilling, Prunus persica, embryo rescue, drupe

'TexKing' is being released by Texas A\&M Univ. to provide a medium-chilling commercially acceptable peach [Prunus persica (Bastch) L.] that ripens after 'Flordaking' and before 'Texstar'. This large, attractive, yellow-flesh peach ripens to allow a continuous supply of fruit during the early May to mid May season in the medium chill zones of the United States.

\section{Origin}

'TexKing' [Prunus persica (Bastch) L.] originated in the Stone Fruit Breeding Program at Dept. of Horticultural Sciences at Texas A\&M Univ., located in College Station, Texas. The seed parent was 'Goldprince', a cultivar released by the U.S. Dept. of Agriculture Stone Fruit Breeding Program located in Georgia (Okie, 1993). The pollen parent was TX3290-2, a large fruited, early ripening, medium chill selection from a cross between the selection Y7-97x 'Hamlet'. Y7-97 was selected at the Yoakum Plant Disease Experiment Station by Hollis Bowen from a population derived from a cross he did at Rutgers Univ. in cooperation with Frederic Hough with pollen from a selection from the Univ. of Florida (Fig. 1). 'Hamlet' is an early ripening peach released from North Carolina Agricultural Experiment Station (Clayton et al., 1977).

The cross was made in 1992, embryos were rescued, and seedlings planted in the high density fruiting nursery at College Station in 1993. 'TexKing' was selected as TX2B6 in 1994 for its early maturity, large fruit size, good productivity, yellow ground color, round shape, high red overcolor, and excellent firmness. It was propagated asexually by budding and has been evaluated in Texas, California, and southern Spain.

\section{Description}

'TexKing' was selected for adaptation in the medium chill zone of south central Texas. It has been fruited in three sites (Yoakum, Floresville, and College Station) in Texas, in California (Clovis), and in southern Spain (Sevilla). The peach selection is adapted in areas where 'Flordaking' (Andrews et al., 1979) and 'Texstar' (Byrne and Kamas, 1984) can be grown commercially. These medium chill regions generally receive at least 450 chilling units as measured by a mean January (coldest month) temperature of $13.9^{\circ} \mathrm{C}$ (Sharpe, 1970). The mean temperature of the coldest month in these areas is between $13.9^{\circ} \mathrm{C}$ to $11.7^{\circ} \mathrm{C}$. It can also be grown in higher chill areas in the absence of temperatures below $-1.7^{\circ} \mathrm{C}$ during flowering and fruit development. During the evaluation of 'TexKing', the chilling received at College Station averaged 750 chilling units, but ranged from 545 to 1088 chilling units.
Fig. 1. Pedigree of 'TexKing'.
The Yoakum site, $\approx 160 \mathrm{~km}$ south of College Station, receives an average of 200 chill units less per year. At both sites, 'TexKing' was as productive as 'Flordaking' and 'Texstar', with average crop ratings of $4.8,4.5$, and 5.0 where a rating of 5 is a full commercial crop (Crop rating scale $0=$ no crop, $2=40 \%$ full crop, 5 = full crop - a fruit every $15 \mathrm{~cm}$ of branch length, $7=\mathrm{a}$ fruit every $7.5 \mathrm{~cm}$ of branch length, and $9=$ a fruit every $3.75 \mathrm{~cm}$ branch length).

The tree is vigorous with a semi-spreading growth habit, as are trees of 'Flordaking' and 'Texstar'. 'TexKing' has moderate resistance to bacterial leaf spot [Xanthomonas campestris pv. pruni (E. F. Smith) Dye.], as does 'Flordaking'. The moderately large leaves are lanceolate with globose glands, acute bases, sharply acute apices, and crenate margins.

'TexKing' blooms with 'Flordaking' and $\approx 13 \mathrm{~d}$ before 'Texstar" (Table 1). Flowers are large and showy with an average diameter of $3.9 \mathrm{~cm}$ and length of petal of $2.0 \mathrm{~cm}$. The five petals are light pink (62C) (Anon., 1995) with a darker pink center vein. The sepals are a dull red (183B). The yellow (8B) anthers have an orange-red (34B) edge and are on filaments (1.5 cm length) and protrude further than the style (average length $1.2 \mathrm{~cm}$ ). Young filaments are white $(155 \mathrm{C})$ and turn red purple $(60 \mathrm{C})$ with age. Pollen is yellow (19B) and abundant. The tree is self fertile.

Trees of 'TexKing' bears crops of early ripening peaches that are firm and large for the season. The fruit is round to ovate, has

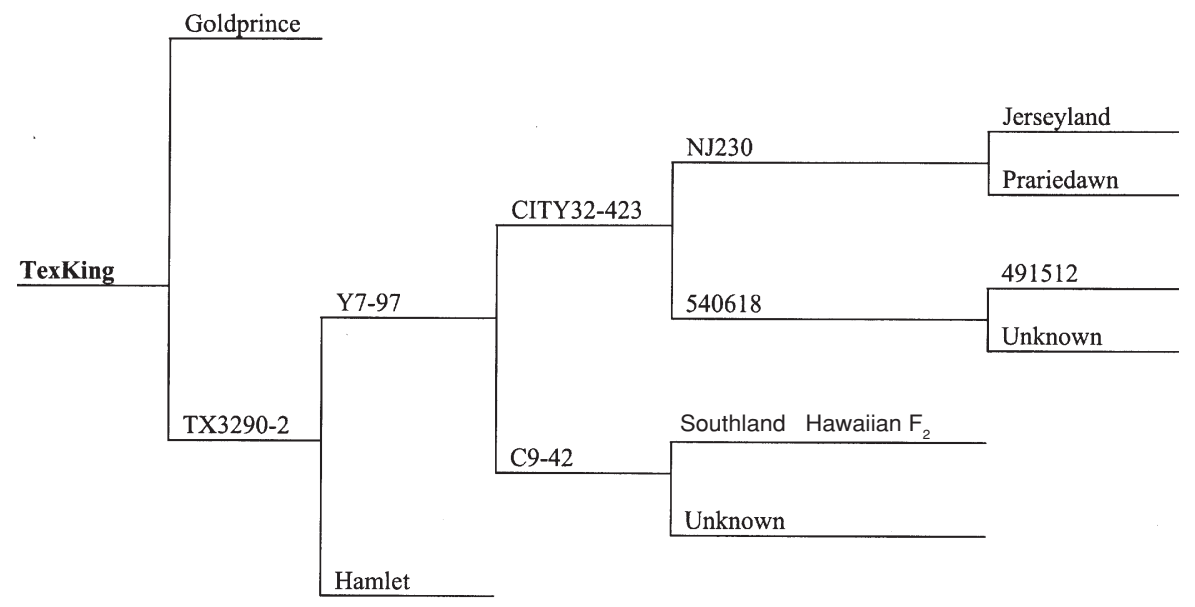

Received for publication 16 Dec. 2003. Accepted for publication 10 Apr. 2003. Research conducted at the Dept. of Horticultural Sciences, College Station, Texas and the Plant Disease Experiment Station, Yoakum, Texas.

${ }^{1}$ Stone Fruit Breeder, Sun World Intl., 16350 Driver Rd., Bakersfield, Calif. 93380-0298.
Table 1. Fruiting characteristics of 'TexKing' compared to three medium chill peach cultivars at College Station, Texas (1994 to 1995,1997 to 2001).

\begin{tabular}{|c|c|c|c|c|c|c|c|c|c|c|c|c|}
\hline Name & $\begin{array}{c}\text { Full } \\
\text { bloom }^{2}\end{array}$ & $\begin{array}{c}\text { FDP } \\
(\text { days })^{z}\end{array}$ & $\begin{array}{l}\text { Ripe } \\
\text { date }^{z}\end{array}$ & $\operatorname{Size}^{y}$ & Firm $^{x}$ & Blush $^{x}$ & Shape $^{x}$ & $\operatorname{Tip}^{x}$ & $\begin{array}{l}\text { Ground } \\
\text { color }^{x}\end{array}$ & $\begin{array}{l}\text { Red in } \\
\text { flesh }^{w}\end{array}$ & Appearance $^{x}$ & Taste $^{\mathrm{x}}$ \\
\hline Flordaking & 15 Feb. $d^{v}$ & $81 \mathrm{c}$ & 6 May d & $6.0 \mathrm{ab}$ & $6.2 \mathrm{c}$ & $4.7 \mathrm{~b}$ & $6.8 \mathrm{a}$ & $6.7 \mathrm{~b}$ & $5.6 \mathrm{~b}$ & $0.0 \mathrm{~b}$ & $6.4 \mathrm{~b}$ & $6.2 \mathrm{~b}$ \\
\hline TexKing ${ }^{\circ}$ & 14 Feb. d & $91 \mathrm{ab}$ & 15 May c & $5.7 \mathrm{~b}$ & $7.1 \mathrm{ab}$ & $7.0 \mathrm{a}$ & $6.9 \mathrm{a}$ & $7.3 \mathrm{ab}$ & $6.0 \mathrm{ab}$ & $0.1 \mathrm{~b}$ & & $6.5 \mathrm{ab}$ \\
\hline & 27 Feb. bc & $85 \mathrm{bc}$ & 23 May b & $4.7 \mathrm{c}$ & $6.7 \mathrm{bc}$ & $5.4 \mathrm{~b}$ & $5.4 \mathrm{~b}$ & $5.1 \mathrm{c}$ & $6.1 \mathrm{ab}$ & $0.1 \mathrm{~b}$ & & $6.7 \mathrm{ab}$ \\
\hline TexRoyal & 6 Mar. ab & 94 a & 6 June a & $5.4 \mathrm{bc}$ & $6.6 \mathrm{bc}$ & $7.2 \mathrm{a}$ & $7.4 \mathrm{a}$ & $7.4 \mathrm{ab}$ & $6.0 \mathrm{ab}$ & $1.3 \mathrm{ab}$ & $6.9 \mathrm{ab}$ & $6.6 \mathrm{ab}$ \\
\hline
\end{tabular}

${ }^{2}$ Full bloom $=60 \%$ to $80 \%$ flowers open, FDP $=$ fruit development period, number of days from full bloom to ripe, Ripe date $=$ date when $20 \%$ fruit is firm ripe stage.

'Size ratings of diameter (mm) 0 to $9,4=51$ to $57,5=58$ to $64,6=65-70,7=71$ to 76 .

${ }^{x}$ Ratings on a subjective 0 to 9 scale, where 0 to $4=$ unacceptable, $5=$ marginal, $6=\operatorname{good}, 7=$ very good, 8 to $9=$ excellent for commercial use.

"Rated on percent basis. $0=$ no red, $5=50 \%$ flesh with red, $9=90 \%$ or more with red.

"Mean separation within columns by Duncan's Multiple Range test at the 5\% level. Means followed by the same letter are not significantly different. No letters within a column indicates no significant differences. 
Table 2. Fruiting characteristics of 'TexKing' compared to three medium chill peach cultivars at Yoakum, Texas (1997 to 2001).

\begin{tabular}{|c|c|c|c|c|c|c|c|c|c|c|}
\hline Name & $\begin{array}{l}\text { Ripe } \\
\text { date }^{z}\end{array}$ & $\operatorname{Size}^{y}$ & Firm $^{x}$ & Blush $^{x}$ & Shape $^{\mathrm{x}}$ & $\operatorname{Tip}^{x}$ & $\begin{array}{l}\text { Ground } \\
\text { color }^{x}\end{array}$ & $\begin{array}{l}\text { Red in } \\
\text { flesh }^{w}\end{array}$ & Appearance ${ }^{x}$ & Taste $^{x}$ \\
\hline Flordaking & 1 May cd $^{\mathbf{v}}$ & $5.7 \mathrm{ab}$ & 6.6 & $5.4 \mathrm{~b}$ & $6.1 \mathrm{ab}$ & $6.0 \mathrm{bc}$ & 5.6 & 0.3 & 5.9 & 6.7 \\
\hline TexKing & 8 May c & $6.3 \mathrm{a}$ & 7.3 & $6.5 \mathrm{ab}$ & $6.8 \mathrm{ab}$ & $7.0 \mathrm{ab}$ & 5.8 & 2.0 & 6.3 & 6.0 \\
\hline Texstar & 19 May b & $4.2 \mathrm{bc}$ & 6.5 & $6.5 \mathrm{ab}$ & $4.8 \mathrm{~b}$ & $5.0 \mathrm{c}$ & 5.9 & 0.0 & 5.7 & 6.8 \\
\hline TexRoyal & 3 June a & $5.0 \mathrm{ab}$ & 6.7 & $7.9 \mathrm{a}$ & $7.5 \mathrm{a}$ & $7.4 \mathrm{ab}$ & 5.9 & 0.7 & 7.1 & 6.8 \\
\hline
\end{tabular}

${ }^{\mathrm{z}}$ Ripe date $=$ date when $20 \%$ fruit is firm ripe stage.

${ }^{y}$ Size ratings of diameter $(\mathrm{mm}) 0$ to $9,4=51$ to $57,5=58$ to $64,6=65$ to $70,7=71$ to 76 .

${ }^{x}$ Ratings on a subjective 0 to 9 scale, where 0 to $4=$ unacceptable, $5=\operatorname{marginal}, 6=$ good, $7=$ very good, 8 to $9=$ excellent for commercial use.

${ }^{\text {w}}$ Rated on percent basis. $0=$ no red, $5=50 \%$ flesh with red, $9=90 \%$ or more with red.

'Mean separation within columns by Duncan's Multiple Range test at the 5\% level. Means followed by the same letter are not significantly different. No letters within a column indicates no significant differences.

a yellow ground color (15C to $18 \mathrm{~B}), 60 \%$ to $80 \%$ red overcolor (46B to $53 \mathrm{~A}$ ), yellow flesh color (14C to $17 \mathrm{C})$, and is clingstone. 'TexKing' has equivalent or better size, firmness, red blush, and shape than 'Flordaking' or 'Texstar'. The fruit has melting flesh that does not brown readily nor has it shown a tendency the medium chill stone fruit production zone of Texas (Tables 1 and 2).

\section{Availability}

A patent has been applied for and budwood can be acquired under a propagation license agreement with the Texas Agricultural Experiment Station.

\section{Literature Cited}

Andrews, C.P., W.B. Sherman, and P.M. Lyrene. 1979. 'Flordaking' Peach. HortScience 14:81-82.

Anon., 1995. RHS Colour Chart. The Royal Hort. Soc., London.

Byrne, D.H. and J.S. Kamas. 1984. 'Texstar' Peach. HortScience 19:453-454.

Clayton, C.N., F.E. Correll, J.R. Ballington, and S.M. Worthington. 1977. Hamlet, Correll, Clayton, and Ellerbe peaches. Fruit Var. J. 31:34-35.

Okie, W.R. 1993. 'Goldprince' and 'Scarletpearl' peaches. HortScience 28:231.

Sharpe, R.H. 1970. Sub-tropical peaches and nectarines. Proc. Fla. State Hort. Soc. 82:302-306. 